\title{
Modulation of obesity-induced inflammation by dietary fats: mechanisms and clinical evidence
}

\author{
Kim-Tiu Teng $^{1 *}$, Chee-Yan Chang ${ }^{2}$, Lin Faun Chang ${ }^{3}$ and Kalanithi Nesaretnam ${ }^{1}$
}

\begin{abstract}
Obesity plays a pivotal role in the development of low-grade inflammation. Dietary fatty acids are important modulators of inflammatory responses. Saturated fatty acids (SFA) and n- 6 polyunsaturated fatty acids (PUFA) have been reported to exert pro-inflammatory effects. n-3 PUFA in particular, possess anti-inflammatory properties. Numerous clinical studies have been conducted over decades to investigate the impact of dietary fatty acids on inflammatory response in obese individuals, however the findings remained uncertain. High fat meals have been reported to increase pro-inflammatory responses, however there is limited evidence to support the role of individual dietary fatty acids in a postprandial state. Evidence in chronic studies is contradictory, the effects of individual dietary fatty acids deserves further attention. Weight loss rather than n-3 PUFA supplementation may play a more prominent role in alleviating low grade inflammation. In this context, the present review provides an update on the mechanistic insight and the influence of dietary fats on low grade inflammation, based on clinical evidence from acute and chronic clinical studies in obese and overweight individuals.
\end{abstract}

Keywords: Inflammation, Obesity, Dietary fats, Saturated fatty acids, Polyunsaturated fatty acids, Adipose tissue

\section{Introduction}

Obesity is a global epidemic in both developed and developing countries. In the United States alone, it is estimated that approximately $69 \%$ of adults are overweight $\left(B M I \geq 25 \mathrm{~kg} / \mathrm{m}^{2}\right)$ and $36 \%$ are obese (BMI $\geq 30 \mathrm{~kg} / \mathrm{m}^{2}$ ) [1]. Obesity is associated with a cluster of metabolic syndrome, which is characterized by hyperglycemia, hypertension, dyslipidemia, reduced high density lipoproteins (HDL) cholesterol and abdominal obesity. Taken together, these metabolic disorders are closely linked to chronic inflammation. Numerous studies have reported that elevated adiposity is associated with increased plasma pro-inflammatory cytokines [2-4].

Weight loss is known to improve obesity-associated metabolic disorders, in particular low grade inflammation [5,6]. However, other dietary interventions aiming at improving obesity-induced inflammation have not been explored in detail. Long chain fatty acids are potent inflammatory mediators [7]. In vivo and in vitro studies have shown the pro-inflammatory effects of saturated

\footnotetext{
* Correspondence: kt.teng@gmail.com

'Product Development and Advisory Services, Malaysian Palm Oil Board (MPOB), 6 Persiaran Institusi, Bandar Baru Bangi, 43000 Kajang, Selangor, Malaysia

Full list of author information is available at the end of the article
}

fats (SFA) [8-10] and polyunsaturated fats (PUFA), in particular n-6 PUFA [11]. In contrast, n-3 PUFA, namely docosahexaenoic acid (DHA) and eicosapentaenoic acid (EPA) have anti-inflammatory properties [12-14]. Nevertheless, the evidence based on clinical studies in this respect is limited and controversial. In this context, the present review provides an update on the mechanistic aspects and the effect of dietary fats on low grade inflammation, based on clinical evidence from acute and chronic clinical studies in obese and overweight individuals.

\section{Obesity-induced inflammation}

Numerous studies found that compared to healthy lean individuals, overweight and obese individuals have higher pro-inflammatory cytokines and lower anti-inflammatory cytokines $[15,16]$. Obesity is characterized by having a greater number of adipose tissue (hyperplasia) and an increase in the size of adipocytes (hypertrophy) $[17,18]$. The aforementioned conditions lead to oxygen depletion in adipose tissue hence causing adipocyte cell death. In addition, the excess storage of triacylglycerols (TAG) from dietary intake results in an excessive influx of free fatty acids into blood circulation. Taken together, this can lead 
to low-grade inflammation characterized by the over production of pro-inflammatory adipocytokines [19].

Adipocytes mediate inflammatory response by regulating the release of free fatty acids and adipocytokines, in particular tumor necrosis factor- $\alpha$ (TNF- $\alpha$ ), interleukin6 (IL-6), and monochemoattractant protein-1 (MCP-1) $[17,20]$. MCP-1 stimulates the recruitment of macrophages into adipose tissue via MCP-1/CC chemokine receptor 2 (CCR2) cascade [21,22]. The findings of macrophage infiltration in adipose tissue provide a mechanistic insight into the obesity-induced low-grade inflammation. This obesity-induced inflammatory state involves a phenotypic switch in adipose tissue macrophage from M2 to M1 state $[23,24]$. The detailed mechanism has been reviewed [25]. In brief, instead of converting monocytes to M2 macrophages, the migration of monocytes from the circulation to the macrophage clusters surrounding dead adipocytes switches M2 to the M1 state. M2 macrophages are also known as alternatively activated macrophages, producing anti-inflammatory cytokines such as interleukin-10 (IL-10) and interleukin-1Ra (IL-1Ra) [17,22,23,25]. M1 macrophages are defined as classically activated macrophages, and produce high concentrations of pro-inflammatory cytokines i.e. TNF- $\alpha$ and IL-6. This phenotypic switch of M2 to M1 is characterized by a reduction in IL-10 and arginase production, in conjunction with an increase in proinflammatory TNF- $\alpha$ production $[23,26]$.

\section{Modulation of inflammation by dietary fatty acids: mechanistic insights \\ Saturated fatty acids}

Numerous in vitro and in vivo studies have shed light on the inflammatory effect of SFA [27-29]. Evidence from a substantial number of studies has reported that SFA stimulate inflammatory response by a pathway involving Toll-like receptors (TLR) (Figure 1). TLR are a class of pattern recognition receptors that play a crucial role in an innate immune system (reviewed in [30]). Elevated levels of TLR-4 have been reported in the obese state whereby the expression was found in many insulin target tissues such as liver, muscle, brain, adipose tissue, vasculature and pancreatic $\beta$-cells [31]. The absence of TLR in studies on mice demonstrated the diminished effect of insulin resistance modulated by pro-inflammatory pathways [32,33].

SFA is the acyl component of lipopolysaccharides (LPS), which is a ligand of TLR-4. It was reported that glycoproteins e.g. myeloid differentiation protein 2 (MD2) and a cluster of differentiation 14 (CD14) are needed for the binding of SFA to TLR-4 [34]. It has also been suggested that there are two pathways involved in the SFA-mediated inflammatory mechanisms, namely TLR-4-dependent and TLR-4-independent pathways (reviewed in [25]). SFA have been reported to induce TLR-4-dependent gene expression

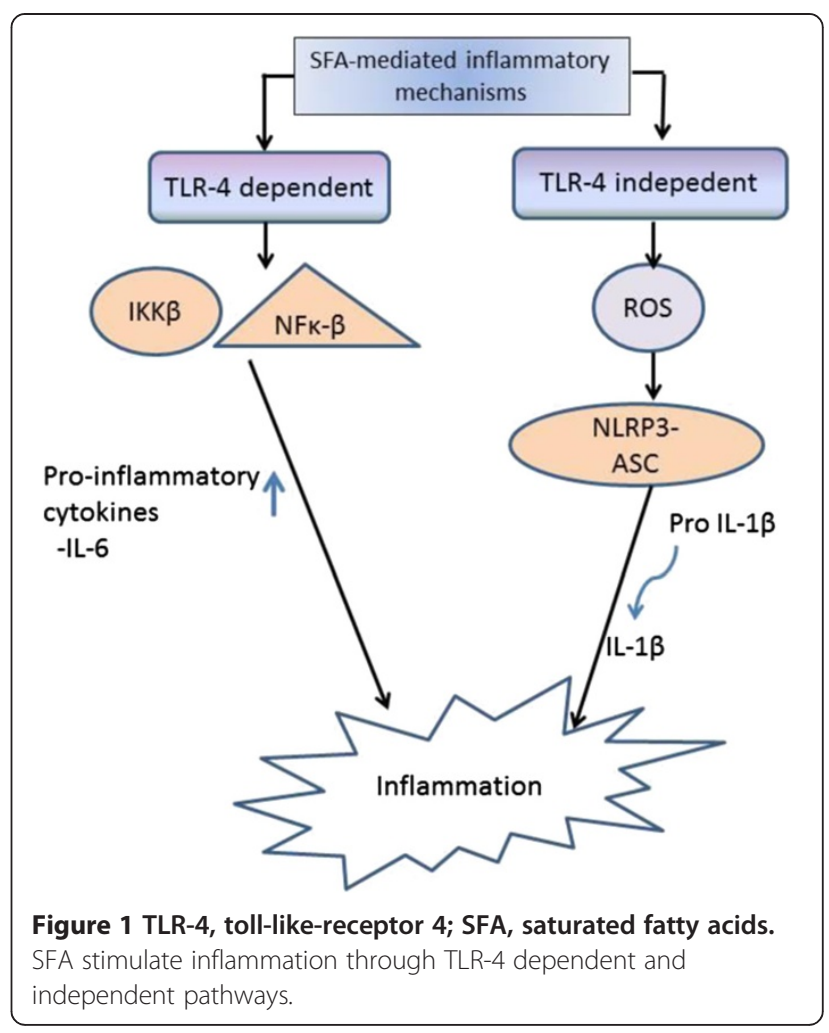

by promoting dimerization of TLR-4, a necessary step in receptor activation, within specialized lipid domains termed "lipid rafts" in macrophages [35]. The stimulatory effects of SFA, lauric, palmitic and stearic acids in particular, have been found to increase IL-6 gene expression in macrophage via the TLR-4 dependent pathway [36]. In line with this, stearic acid has also been found to stimulate the release of MCP-1 expression via TLR-4 [37]. TLR-4 activates pro-inflammatory pathways by stimulating the expression of transcription factors, including IKK $\beta$ and NF- $\mathrm{B} B[31,32]$.

Other than the TLR-dependent pathway, SFA stimulate pro-inflammatory mechanisms through the TLR-indepen dent pathway by producing reactive oxygen species (ROS). ROS activate nucleotide-binding domain, leucine-rich repeat containing family, pyrin domain-containing 3 (NLRP3) inflammasome [38] that forms a complex with apoptotic speck protein (ASC), known as NLRP3- ASC inflammasome complex [39]. This complex regulates the cleavage of interleukin-1 $\beta$ (IL-1 $\beta)$ from pro-IL-1 $\beta[40,41]$. The release of IL-1 $\beta$ decreases insulin signalling in insulin target cells, providing a possible SFA-mediated inflammatory response leading to insulin resistance $[42,43]$.

\section{Polyunsaturated fatty acids}

n-6 PUFA, also known as linoleic acid (LA) is thought to be pro-inflammatory and it can be converted into arachidonic acid (AA) [44]. AA is the major substrate for 
eicosanoids production, which plays an important role in regulating inflammatory and immune responses [45]. Eicosanoids consist of prostaglandins, prostacyclins, thromboxanes, and leukotrienes. Biosynthesis of eicosanoid products are regulated by three major enzymes, namely cyclooxygenases, lipoxygenases and cytochrome P450s [46]. Most of the AA-derived eicosanoid products are pro-inflammatory, except prostaglandins E2 $\left(\mathrm{PGE}_{2}\right)$ and lipoxins which have anti-inflammatory effects $[47,48]$.

n-3 PUFA, namely linolenic acid (ALA) is known to exhibit anti-inflammatory properties $[12,14,49]$. Deep sea fish like salmon and mackerel are sources of n-3 PUFA. n-3 PUFA can be converted into EPA and DHA [44]. A number of reviews have been reported on the anti-inflammatory mechanisms of n-3 PUFA (Figure 2) $[26,45,50]$. One of the anti-inflammatory effects of $n-3$ PUFA is the downregulation of pro-inflammatory cytokines in adipose tissue such as TNF- $\alpha$, IL- 6 and MCP-1, which can be explained by several possible pathways [34,50-53]. The first possible pathway is the binding of EPA and DHA with the G protein-coupled receptor 120 (GPR120) [54]. Activated GPR120 internalizes as plasma membrane with $\beta$ arrestin2 to form GPR120/ $\beta$-arrestin2 complex. The complex which then associates with $\mathrm{TAB} 1$, results in the inhibition of TAK1 and prevents the downstream signalling to NF- $\mathrm{kB}$ and JNK systems [53].
While SFA were found to stimulate TLR-4 signalling, EPA and DHA were found to inhibit the TLR-4 signalling pathway [34]. The TLR-4 signalling pathway may be blocked by DHA and EPA through the downregulation of nicotinamide adenine dinucleotide phosphase-oxidase (NADPH oxidase) production [50]. NADPH oxidase induces ROS production, which is found to be necessary for TLR-4 signalling [51]. In addition, the incorporation of DHA into lipid membrane disrupts the translocation of TLR-4 into lipid raft, thus inhibiting the TLR-4 signalling pathway [50,55]. The disrupted TLR-4 signalling pathways lead to the inhibition of NF- $\mathrm{kB}$ thus resulting in the downregulation of inflammatory responses [53,54]. These findings indicate that the intake of EPA and DHA reduces the secretion of pro-inflammatory cytokines, and it may also be possible that these n-3 PUFA play a role in preventing macrophage infiltration into adipose tissue [50]. Findings from human $[49,56]$ and rodent [57] studies reported that the production of adiponectin increases with a higher intake of EPA and DHA. However, the upregulation of adiponectin secretion may be associated with peroxisome proliferator- activated receptor $\gamma$ (PPAR $\gamma$ ) activation $[57,58]$. The upregulation of leptin by DHA is found to have a similar pathway with adiponectin [50]. It was suggested that a diet rich in EPA and DHA results in a higher incorporation of these fatty acids into

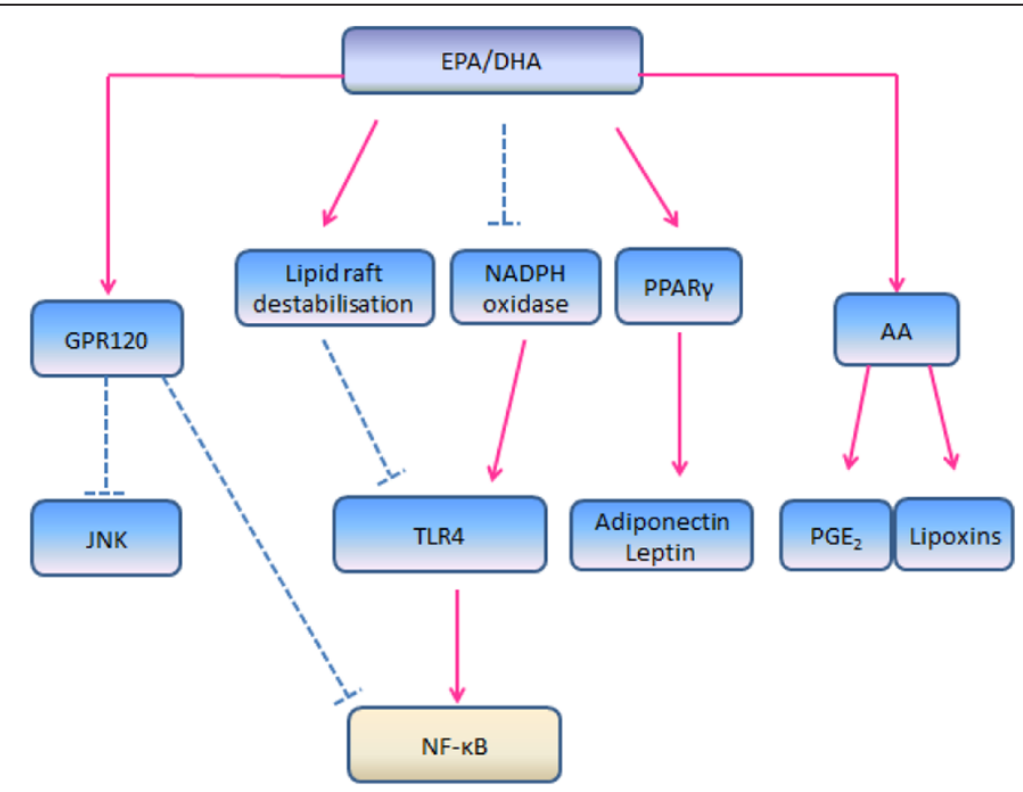

Figure 2 Dotted line, inhibit; solid line, activate. EPA, eicosapentaenoic acid; DHA, docosahexaenoic acid; GPR120, G protein-coupled receptor

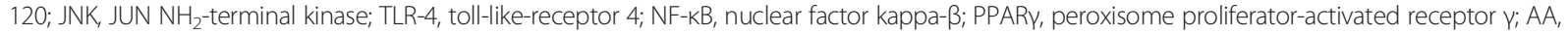
arachidonic acid; $\mathrm{PGE}_{2}$, prostaglandins E2. Anti-inflammatory mechanisms of EPA and DHA. EPA and DHA inhibit NF-KB and JNK through binding with GPR120. Incorporation of these n-3 PUFA disrupts the translocation of TLR-4 into lipid raft, thus inactivates NF-KB pathway. Besides, EPA and DHA interfere with the TLR-4 signaling pathway via the downregulation of NADPH oxidase production, which results in the inhibition of NF-KB pathway. These fatty acids also activate PPARY and, result in the upregulation of adiponectin and leptin secretion. In addition, the intake of EPA and DHA leads to antagonism of n-6 fatty acid arachidonic acid (AA). 
phospholipid membrane, compared to AA. Therefore, a higher intake of EPA and DHA may reduce the production of AA-derived eicosanoid products, thereby providing another n-3 PUFA induced anti-inflammatory effect [47].

\section{Clinical evidence}

Numerous prospective epidemiological studies have reported association between dietary fats and low grade inflammation. However, it is noteworthy that the effect may be speculative based on the association between changes in plasma fatty acids and levels of inflammatory cytokines. Clinical evidence provides a direct measurement of the impact of dietary intake on circulating inflammatory markers. Hence in the present review, clinical studies were identified by searching Pubmed, EMBASE, Cochrane databases. Inclusion criteria were English language articles reporting the measurement of at least one inflammatory marker including cytokines, vascular adhesion molecules, $\mathrm{C}$-reactive proteins (CRP) in both postprandial and fasting measurements following the ingestion of high fat meals or dietary intervention (3-week and above) in overweight and obese individuals $\left(B M I \geq 25 \mathrm{~kg} / \mathrm{m}^{2}\right.$ or waist circumference $>80 \mathrm{~cm}$ for women and $>90 \mathrm{~cm}$ for men) for the last 10 years. Studies investigating subjects under $18 \mathrm{y}$, lean and healthy, taking antioxidant supplements, pregnant and lactating, having chronic inflammatory related diseases were excluded. A total of 9 papers on acute studies and 12 papers on chronic studies were included in the following discussion.

\section{Acute dietary intake}

\section{Amount of dietary fats on postprandial inflammatory response}

Postprandial lipemia provokes the release of pro-inflam matory markers and impairs insulin response. A repetitive exposure of endothelial cells to pro-inflammatory cytokines leads to the progression of chronic diseases such as diabetes and cardiovascular diseases $[59,60]$. Previous studies found that postprandial inflammation is augmented in obese and overweight individuals as cytokines are secreted by adipose tissue $[16,61]$. The quantity of fat is thought to have greater impact on postprandial inflammatory response in overweight and obese than in healthy lean individuals [15]. This hypothesis is supported by a recent study which reported that the consumption of a high fat mixed meal increased plasma IL- 6 and hsCRP concentrations compared with water (control) in 10 obese males [62] (Table 1). The mixed meal consisted of $57.5 \mathrm{~g}$ dietary fat (with $29 \mathrm{~g}$ saturated fat) derived from bacon, egg muffin, 2 hash browns with a glass of caramelflavored milk drink. The mixed meal however did not alter plasma TNF- $\alpha$ and adiponectin concentrations and the similar observations were reported after the water intake. Manning et al. [16] however reported that both low and high fat meals increased plasma IL- 6 concentrations but had no effect on plasma TNF- $\alpha$ and IL-8 concentrations in 15 obese women. The low fat meals were mashed potato (12 g fat) or all bran (13 g fat), whereas high fat meals were $200 \mathrm{~g}$ instant mashed potato enriched with cream (high SFA, 71 g), olive oil (high monounsaturated fats (MUFA), $72 \mathrm{~g}$ ) or canola oil (high PUFA, $72 \mathrm{~g}$ ). The low and high fat meals were not iso-caloric and the obese women ingested fats in proportion with their body weight. These conflicting findings may be explained by the differences in study design; (1) gender (men vs. women), (2) control used (water vs. $12 \mathrm{~g}$ fat), (3) amount of fat in high fat meals $(57.5 \mathrm{~g}$ vs. $0.6 \mathrm{~g} / \mathrm{kg}$ in proportion with body weight, which is equivalent to $72 \mathrm{~g}$ total fat), (4) composition of mixed meals and (5) measurement time point.

The discrepancies observed in these two studies may further be explained by a study conducted by Blackburn et al. [63]. A relatively larger sample size with 38 obese men ingested a high fat mixed meal consisted of eggs, cheese, toast, peanut butter, whipped cream, peaches and milk. The total fat was given at $60 \mathrm{~g} / \mathrm{m}^{2}$ body surface area. This has resulted in an increase in plasma IL-6 concentrations but TNF- $\alpha$ and hsCRP concentrations remained unchanged. Miglio et al. [64] however observed an increase in postprandial plasma TNF- $\alpha$ concentrations following the ingestion of $82 \mathrm{~g}$ high fat mixed meal. In the study, 15 overweight men and women ingested a high fat mixed meal consisted of fried potatoes, fried eggs, Emmenthal cheese, and Italian rose-shaped dinner rolls, served with $500 \mathrm{ml}$ low sugar content beverage. These discrepant of findings could be attributed to the different time point of blood sampling. The results observed by Blackburn et al. [63] at $4 \mathrm{~h}$ after meal commencement may have prevented the notice of an early increase in plasma TNF- $\alpha$ concentrations, as observed by Miglio et al. [64] at $1 \mathrm{~h}$ after meals. Amount of fat used by Miglio et al. [64] was higher compared to other studies $[16,62,63]$, but a previous study reported that the ingestion of meals enriched with $50 \mathrm{~g}$ of fats enabled the detection of postprandial changes in plasma IL- 6 and TNF- $\alpha$ concentrations in healthy subjects [65]. This suggests that the studies discussed have incorporated sufficient amount of fats to detect the postprandial changes in plasma cytokines.

The activation of NF-kB has been reported to regulate the release of cytokines during postprandial period [66]. Patel et al. [15] reported that a high fat, high carbohydrate meal increased the ROS generation and NF- $\mathrm{kB}$ binding activities in 8 obese subjects ( 3 men and 5 women). In the study, subjects consumed a high fat mixed meal consisted of a Big Mac, a large French fries, a large Coke and an apple pie, providing approximately $60 \mathrm{~g}$ of fats. However, the postprandial duration was relatively short $(3 \mathrm{~h})$ and 
Table 1 Acute effects of the amount of dietary fats on inflammatory response in obese or overweight individuals

\begin{tabular}{|c|c|c|c|c|c|}
\hline Subjects: $n$ (F/M) & $\begin{array}{l}\text { Postprandial } \\
\text { duration }\end{array}$ & Test meal & $\begin{array}{l}\text { Inflammatory } \\
\text { response in } \\
\text { overweight/obese } \\
\text { individuals }\end{array}$ & Remarks & References \\
\hline \multirow[t]{2}{*}{$\begin{array}{l}\text { Lean: } 10(-/ 10) \\
\text { Obese: } 10(-/ 10) \\
\text { T2DM: } 10(-/ 10)\end{array}$} & $\begin{array}{l}0,1,2,3,4,5 \\
6 \mathrm{~h}\end{array}$ & $\begin{array}{l}\text { HFM: } 57.5 \mathrm{~g} \text { fat ( } 29 \mathrm{~g} \text { SFA) } \\
\text { A bacon and egg muffin, } 2 \text { hash browns, } \\
\text { caramel flavored milk drink ( } 250 \mathrm{ml} \text { of } 4 \% \\
\text { fat milk, } 4 \text { teaspoons skim milk powder } \\
\text { and } 1 \text { teaspoon caramel flavor) }\end{array}$ & $\begin{array}{l}\text { IL-6, hsCRP: HFM } \uparrow \\
\text { over time; NS } \\
\text { TNF-a: =; NS } \\
\text { Total adiponectin: } \\
\text { HFM } \uparrow \text { over time; NS } \\
\text { HMW adiponectin: =; NS }\end{array}$ & $\begin{array}{l}\text { Sample size was calculated } \\
\text { based on the changes of } \\
\text { adiponectin, but not other } \\
\text { markers }\end{array}$ & {$[62]$} \\
\hline & & Water (control) & & Small sample size & \\
\hline \multirow[t]{6}{*}{$\begin{array}{l}\text { Lean: } 14(14 /-) ; \\
\text { obese: } 15(15 /-)\end{array}$} & $0,1,4,6 \mathrm{~h}$ & $\begin{array}{l}\text { SFA: } 71 \mathrm{~g} \text { fat ( } 18 \mathrm{~g} \text { palmitate) } \\
\text { Instant potato with } 16 \mathrm{~g} \text { cream } / \mathrm{kg} \text { body } \\
\text { weight, } 100 \mathrm{ml} \text { hot water }\end{array}$ & $\begin{array}{l}\mathrm{IL}-6: \downarrow \text { at } 1 \mathrm{~h}, \uparrow \text { at } 6 \mathrm{~h} ; \mathrm{NS} \\
\mathrm{IL}-8, \text { TNF-a: }=; \mathrm{NS}\end{array}$ & $\begin{array}{l}\text { Timing of menstrual cycle } \\
\text { and oral contraceptive usage } \\
\text { were not taken into account }\end{array}$ & [16] \\
\hline & & $\begin{array}{l}\text { MUFA: } 72 \mathrm{~g} \text { fat ( } 9 \mathrm{~g} \text { palmitate ) } \\
\text { Instant potato with } 0.6 \mathrm{~g} / \mathrm{kg} \text { body weight } \\
\text { of olive oil, } 160 \mathrm{ml} \text { hot water }\end{array}$ & & $\begin{array}{l}\text { Subjects with hypertension } \\
\text { and dyslipidemia were included }\end{array}$ & \\
\hline & & $\begin{array}{l}\mathrm{n}-6 \text { PUFA: } 72 \mathrm{~g} \text { fat ( } 5 \mathrm{~g} \text { palmitate) } \\
\text { Instant potato with } 0.6 \mathrm{~g} / \mathrm{kg} \text { body weight } \\
\text { of canola oil, } 160 \mathrm{ml} \text { hot water }\end{array}$ & & $\begin{array}{l}\text { Test meals were not iso-caloric } \\
\text { Small sample size. }\end{array}$ & \\
\hline & & $\begin{array}{l}\text { LFM-potato: } 12 \mathrm{~g} \text { fat ( } 3 \mathrm{~g} \text { palmitate) } \\
\text { Instant potato, } 160 \mathrm{~m} / \text { hot water. }\end{array}$ & & & \\
\hline & & $\begin{array}{l}\text { LFM - bran: } 13 \mathrm{~g} \text { fat ( } 3 \mathrm{~g} \text { palmitate) } \\
\text { All-Bran, } 40 \mathrm{ml} \text { trim milk, and } 2 \text { cooked eggs }\end{array}$ & & & \\
\hline & & *test meals for obese subjects only & & & \\
\hline Obese: 38 (-/38) & $0,4,8 \mathrm{~h}$ & $\begin{array}{l}60 \mathrm{~g} \mathrm{fat} / \mathrm{m}^{2} \text { body surface } \\
\text { Eggs, cheese, toast, peanut } 7, \text { whipped } \\
\text { cream, peaches and milk }\end{array}$ & $\begin{array}{l}\text { IL-6: } \uparrow \text { at } 6 \mathrm{~h} \\
\text { TNF-a: } \downarrow \text { at } 4 \mathrm{~h}\end{array}$ & Control not included & [63] \\
\hline $\begin{array}{l}\text { Overweight: } \\
15(2 / 13)\end{array}$ & $\begin{array}{l}0,0.5,1,2,4,6, \\
8 \mathrm{~h}\end{array}$ & $\begin{array}{l}82 \mathrm{~g} \text { fat ( } 36.9 \mathrm{~g} \mathrm{SFA}) \\
\text { Fried potatoes, fried eggs, Emmenthal } \\
\text { cheese, Italian rose-shaped dinner rolls, } \\
\text { with } 500 \mathrm{ml} \text { of low sugar content beverage }\end{array}$ & $\begin{array}{l}\text { IL-6, TNF-a: } \uparrow \text { over } \\
\text { time }\end{array}$ & $\begin{array}{l}\text { Small sample size } \\
\text { Control not included } \\
\text { Short postprandial period }\end{array}$ & {$[64]$} \\
\hline $\begin{array}{l}\text { Lean: } 10(5 / 5) ; \\
\text { Obese: } 8(5 / 3)\end{array}$ & $0,1,2,3 \mathrm{~h}$ & $\begin{array}{l}\text { HFM, } 60 \mathrm{~g} \text { fat } \\
\text { Big Mac, large French fries, a large Coke, } \\
\text { and apple pie }\end{array}$ & $\begin{array}{l}\text { ROS generation and } \\
\text { NF-KB binding : } \uparrow \\
\text { over time }\end{array}$ & $\begin{array}{l}\text { Small sample size } \\
\text { Short postprandial period } \\
\text { Control not included }\end{array}$ & [15] \\
\hline
\end{tabular}

HFM, high fat meal; LFM, low fat meal; SFA, saturated fats; MUFA, monounsaturated fats; PUFA, polyunsaturated fats; \% en, percentage energy; IL, interleukin; hsCRP, high-sensitivity C-reactive protein; TNF-a, tumor necrosis factor- alpha; sICAM-1, soluble intracellular adhesion molecule-1; sVCAM-1, soluble vascular adhesion molecule-1; HMW, high molecular weight; AUC, area under the curve; ROS, reactive oxygen species; NF-KB, nuclear factor kappa- $\beta$; $\downarrow$, reduced postprandial concentrations; $\uparrow$, increased postprandial concentrations; $=$, no postprandial/after meal effect; $\uparrow \uparrow$, higher postprandial increment compared to other meals; NS, no significant difference between meals.

changes in plasma cytokines concentrations were not measured; hence the relation between NF-kB and the release of cytokines deserves further investigation. Taken together the evidence available, the consumption of high fat meals may lead to the increase of postprandial inflammatory markers, in particular plasma IL-6, as well as the ROS generation and NF- $\mathrm{kB}$ binding activities in overweight and obese individuals.

\section{Type of dietary fats on postprandial inflammatory response}

Masson and Mensink [67] reported that in 13 overweight men, plasma IL-6, TNF- $\alpha$ and soluble vascular adhesion molecule-1 (sVCAM-1) concentrations decreased after n-6 PUFA meal, while the markers were increased after SFA meal (Table 2). The subjects were randomly assigned to high fat meal enriched with $50 \mathrm{~g}$ butter (SFA meal), or $40 \mathrm{~g}$ margarine plus $10 \mathrm{~g}$ safflower oil (n-6 PUFA meal). Both test meals were served in the form of muffins (two per subject) with a glass of water (250 ml). Interestingly, decreased plasma MCP-1 concentrations were observed after both high fat meals, while no meal effect was reported for plasma IL-8 and soluble intracellular adhesion molecule-1 (sICAM-1) concentrations. In contrast, Manning et al. [16] observed that all high fat meals regardless of type of fats increased plasma IL-6 concentrations in a similar manner but had no impact on plasma IL- 8 and TNF- $\alpha$ concentrations in 15 obese women. The inconsistencies of results reported by these two studies may be explained by the gender differences (men vs. women) of the subjects as discussed earlier. Furthermore, the differing content of linoleic 
Table 2 Acute effects of the type of dietary fats on inflammatory response in obese or overweight individuals

$\begin{array}{lll}\text { Subjects: } n \text { (F/ } & \begin{array}{l}\text { Postprandial } \\ \text { duration }\end{array} & \text { Test meal }\end{array}$

Overweight:

Overweight:
$13(-113)$

$0,15,30,45, \quad$ SFA: $56.6 \mathrm{~g}$ fat (33.9 g SFA)

$60,90 \mathrm{~min}, 2, \quad 2$ muffins with butter and $250 \mathrm{ml}$

$3,4,5,6,7,8$ h water

n-6 PUFA: $60.5 \mathrm{~g}$ fat (12.9 g SFA, $21.8 \mathrm{~g}$ PUFA)

2 muffins with $40 \mathrm{~g}$ butter and $10 \mathrm{~g}$ margarine, and $250 \mathrm{~m} /$ water

Lean: $14(14 /-)$

Obese: 15 (15/-)

$0,1,4,6 \mathrm{~h}$

A low fat lunch was served after $3 \mathrm{~h}$

SFA: $71 \mathrm{~g}$ fat (18 g palmitate)

Instant potato with $16 \mathrm{~g}$ cream $/ \mathrm{kg}$ body weight, $100 \mathrm{ml}$ hot water

MUFA: $72 \mathrm{~g}$ fat (9 g palmitate)

Instant potato with $0.6 \mathrm{~g} / \mathrm{kg}$ body weight of olive oil, $160 \mathrm{ml}$ hot water

n-6 PUFA:72 g fat (5 g palmitate) Instant potato with $0.6 \mathrm{~g} / \mathrm{kg}$ body weight of canola oil, $160 \mathrm{ml}$ hot water

LFM-potato: $12 \mathrm{~g}$ fat (3 g palmitate) Instant potato, $160 \mathrm{ml}$ hot water.

LFM - bran: $13 \mathrm{~g}$ fat (3 g palmitate)

All-Bran, $40 \mathrm{ml}$ trim milk, and 2 cooked eggs

*test meals for obese subjects only

Lean: $18(-/ 18) \quad 0,2,4 \mathrm{~h}$

Obese: $18(-/ 18)$

Lean: $18(-/ 18)$

Obese: $18(-/ 18)$

Obese diabetic:

$6(-/ 6)$

\section{$0,2,4 \mathrm{~h}$}

SFA: $95 \mathrm{~g}$ fat (51 g SFA)

Shakes containing low fat yogurt, low fat milk, strawberry flavor, sugar and $95 \mathrm{~g}$ palm oil

MUFA: $95 \mathrm{~g}$ fat (8 g SFA)

Shakes containing low fat yogurt, low fat milk, strawberry flavor, sugar and $95 \mathrm{~g}$ high oleic sunflower oil

n-3 PUFA: $95 \mathrm{~g}$ fat (32 g SFA)

Shakes containing low fat yogurt, low fat milk, strawberry flavor, sugar and $40 \mathrm{~g}$ palm oil $+55 \mathrm{~g}$ Marinol D40 (40\% DHA).

SFA: $95 \mathrm{~g}$ fat ( $51 \mathrm{~g}$ SFA)
Shakes containing low fat yogurt, low fat milk,
strawberry flavor, sugar and $95 \mathrm{~g}$ palm oil

MUFA: $95 \mathrm{~g}$ fat (8 g SFA)

Shakes containing low fat yogurt, low fat milk, strawberry flavor, sugar and $95 \mathrm{~g}$ high oleic sunflower oil

n-3 PUFA: $95 \mathrm{~g}$ fat (32 g SFA)

Shakes containing low fat yogurt, low fat milk, strawberry flavor, sugar and $40 \mathrm{~g}$ palm oil $+55 \mathrm{~g}$ Marinol D40 (40\% DHA)

Obese/

overweight:

$0,1,2,4,6 \mathrm{~h}$

$10(6 / 4)$
SFA: $83 \mathrm{~g}$ fat

Refined palm oil blended with $1 \%$ milk, strawberry flavored syrup, low fat frozen, and non-fat dry milk powder.

Inflammatory

Remarks

response in

overweight/obese

individuals

IL-6, TNF-a, sVCAM-

1: SFA $\uparrow$, PUFA $\downarrow$

MCP-1: $\downarrow$ over time;

NS SICAM-1: = ; NS

Small sample size

[67]

References

at 6 h; NS

IL-8, TNF-a: =; NS

Timing of menstrual cycle and oral contraceptive usage were not taken into account

Subjects with hypertension and dyslipidemia were included

Test meals were not isocaloric

Small sample size

IL-8: $\uparrow$ over time; NS IL-6: $\downarrow$ over time; NS CRP: $=$; NS

$\mathrm{IL}-1 \beta$ and

TNF- $a$ : $=$; NS

PBMC MCP-1 and IL-8: MUFA and n-3

PUFA $\uparrow \uparrow, S F A \uparrow$ at $4 \mathrm{~h}$
Short postprandial

period

Small sample size
[16]

(1)




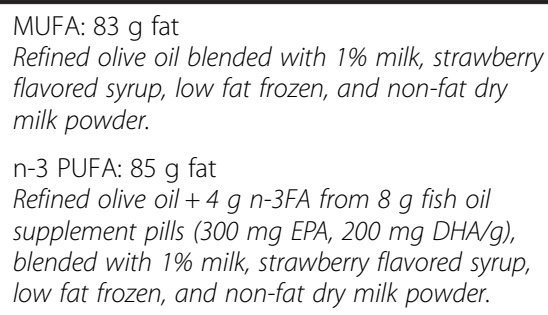

LFM, low fat meal; SFA, saturated fats; MUFA, monounsaturated fats; PUFA, polyunsaturated fats; \% en, percentage energy; IL, interleukin; hsCRP, high-sensitivity Creactive protein; TNF- $a$, tumor necrosis factor- alpha; SICAM-1, soluble intracellular adhesion molecule-1; SVCAM-1, soluble vascular adhesion molecule-1; TAG, triacylglycerols; MCP-1, monochemoattractant protein-1; PBMC, peripheral blood mononuclear cells AUC, area under the curve; $\downarrow$, reduced postprandial concentrations; $\uparrow$, increased postprandial concentrations; $=$, no postprandial/after meal effect; $\uparrow \uparrow$, higher postprandial increment compared to other meals; NS, no significant difference between meals.

acids (20 g vs. $14 \mathrm{~g}$ for $\mathrm{n}-6$ PUFA meals), may attribute to the discrepant findings. Evidence from in vitro findings suggested a pro-inflammatory effect of n-6 PUFA, however the effect is uncertain in human studies [68]. In addition, the sources of SFA (butter vs. cream) used may attribute to the diversifying results. Butter contains substantial amount of medium chain triglycerides which may be better absorbed compared with cream with different physical characteristics [69].

The following three studies reported that n-3 PUFA had no favorable impact on the postprandial responses of plasma cytokines when compared with MUFA or SFA rich oils. Esser et al. [61] provided 18 obese men SFA (95 g palm oil), MUFA (95 g high oleic sunflower oil), or $\mathrm{n}-3$ PUFA (40 g palm oil plus $55 \mathrm{~g}$ Marinol D-40) enriched shakes. The study reported that the high fat meals increased plasma IL-8 concentrations, and reduced plasma IL- 6 concentrations in a similar magnitude but no impact on plasma CRP concentrations. Another similar study by Van Dijk et al. [70] reported null effects on plasma IL- $1 \beta$ and TNF- $\alpha$ concentrations in obese men, irrespective of the type of fats consumed (refined palm oil as SFA, refined olive oil as MUFA, and refined olive oil plus $4 \mathrm{~g}$ of $\mathrm{n}$-3FA from $8 \mathrm{~g}$ fish oil supplement pills as n-3PUFA). The study however, observed lower peripheral blood mononuclear cells (PBMC) MCP-1 and IL-8 concentrations after SFA compared with MUFA and n-3 PUFA high fat meals in obese men. This observation concurs with an earlier study in 10 obese overweight subjects [71]. Although the postprandial effect on plasma cytokines (CRP, TNF- $\alpha$, sICAM-1 and sVCAM-1) did not vary, n-3 PUFA was found to activate NF-kB expression compared with SFA. The authors explained that the lower activation of NF- $\kappa B$ by SFA may be attributed to the palmitate content in the palm oil, as in vitro studies have shown that high levels of palmitate may suppress NF- $\mathrm{kB}$ activation [27]. Despite the diminished effect on plasma cytokines, the activation of NF- $\mathrm{kB}$ may suggest that the synthesis and secretion processes of plasma cytokines may not occur concurrently in the cell and extracellular tissue, hence suggesting that a complex pathophysiological mechanism involved.

Evidence to-date suggests that there is no clear beneficial effect of the consumption of PUFA rich meals on postprandial plasma inflammatory cytokines. On the other hand, SFA rich meals may not be detrimental in an acute feeding scenario in obese and overweight individuals. However, high fat meal may promote elevated postprandial inflammatory response, with limited evidence on varying cytokines. It is also important to understand that the repetitive exposure of dietary fatty acids on the whole body homeostasis may only be observed in longterm dietary intervention studies.

\section{Chronic dietary intervention}

\section{Effects of the type of dietary fats on inflammation}

n-6 PUFA (particularly of linoleic acid), is negatively viewed as pro-inflammatory considering the fact that it can be metabolized into AA and subsequent undesirable metabolites. Furthermore, n-6 PUFA may compete for cyclooxygenase thus reducing the formation of antiinflammatory mediators from n-3 PUFA [72]. Nevertheless, a rigorously well conducted systematic review reported that no clinical evidence to-date were able to suggest the pro-inflammatory effects of linoleic acid in healthy, noninfant individuals [73]. However these findings may need further confirmation in overweight and obese individuals. The baseline levels of inflammatory markers in lean healthy individuals are appreciably lower compared to an overweight population. Hence the impact of dietary fatty acids may virtually be negligible in lean healthy population. Two recent studies in obese individuals however have reported discrepant findings (Table 3). Kralova Lesna et al. [74] conducted a 3-week dietary intervention with predominant PUFA (25\% en PUFA from vegetable oils) or SFA (29\% en SFA from animal fat content) in 14 overweight, dyslipidemic and 
postmenopausal women. The study reported that a relatively high intake of PUFA decreased plasma CRP compared with baseline but no comparison was made between diets. The small sample size and short study duration with limited statistical interpretation may reduce the strength of findings. In addition, Bjermo et al. (2012) reported that n-6 PUFA decreased plasma IL-1RA and TNF-R2 concentrations compared with a SFA-enriched diet after a 10-week iso-caloric dietary intervention in 61 abdominally obese individuals [75]. n-6 PUFA (from sunflower oil) was exchanged at $10 \%$ en with SFA derived predominantly from butter. The well powered study with longer duration may explain the positive findings of $n-6$ PUFA. However, the results generated may be less convincing based on the high noncompliance reported (PUFA, $16 \%$; SFA, 34\%). Furthermore, it is to be noted that the non-equally distributed participants (16-31\%) on antihypertensive and lipid-lowering drugs, may confound the levels of circulating cytokines in a parallel study [76,77].

The anti-inflammatory effects of n-3 PUFA has been confirmed in prospective epidemiological and in vitro findings. Thus, the anti-inflammatory potential of $n-3$ PUFA has been put to a rigorous test in clinical trials. However, five studies reported conflicting findings. Maki et al. [78] reported that supplementation of krill oil (216 mg EPA, $90 \mathrm{mg}$ DHA), menhaden oil (212 mg DHA, 178 mg EPA) or control (2 g olive oil) for 4-week to 25 overweight individuals did not alter plasma CRP. In contrary, Kiecolt-Glaser et al. (2012) reported that the consumption of two doses of n-3 PUFA (1.25 vs $2.5 \mathrm{~g} /$ day, EPA: DHA ratio is 7:1) for 4 months in $46 \mathrm{ab}-$ dominally overweight individuals resulted in discernable reduction in plasma TNF- $\alpha$ and IL- 6 concentrations [79]. It is plausible that the longer duration with sufficiently powered design enable the detection of positive findings. Furthermore, ideal balance of EPA to DHA may play a critical role as evidence suggests that EPA may be more anti-inflammatory than DHA [80,81]. In agreement with Kiecolt-Glaser et al. [79], a recent study found that 55 severely obese nondiabetic patients provided with $3.36 \mathrm{~g}$ n-3 PUFA (EPA, DHA) for 8-week experienced a marked decrease in plasma IL- 6 but not hsCRP concentrations [82]. Interestingly, the study also reported that n-3 PUFA decreased the expression of varying inflammatory genes in subcutaneous adipose tissue and increased the production of eicosanoids in both visceral and subcutaneous adipose tissue compared with butter fat (control). The beneficial effect of n-3 PUFA was evident in severely obese patients (BMI $\geq$ $40 \mathrm{~kg} / \mathrm{m}^{2}$ ) and this again proven that the impact of dietary fats on plasma cytokines is attributed to the baseline levels of circulating cytokines.

To investigate the plant-based n-3 PUFA, namely ALA, Nelson et al. [83] fed healthy abdominally overweight individuals with flaxseed oil (5\% en ALA of total energy intake or $11 \mathrm{~g} /$ day, $\mathrm{n}=27)$ or habitual diet $(\mathrm{n}=24)$, in a parallel design for 8-week. The targeted fat exchange with ALA was achieved at $10 \mathrm{~g} /$ day or $4.6 \%$ en of total fat intake as reported by self-reporting dietary record. No significant changes was observed for plasma IL-6, TNF- $\alpha$ and CRP concentrations. However, measurable increase of EPA and DHA was detected in erythrocyte cell membranes suggesting the conversion of ALA to EPA and DHA in the relatively short study duration. The primary differences between this study and previously reported were the fat source (plant-based ALA), younger age $(\sim 38$ $y$ ), and relatively healthy overweight individuals. This further supports the hypothesis that the baseline levels of cytokines were too low for any discernable changes. Taken together, the effect of dietary fats, in particular n-6 PUFA required further confirmation. The beneficial effects of n-3 PUFA may only be observed in severely obese individuals with higher baseline levels of plasma cytokines. Further studies bridging the gap of information are needed.

\section{Restricted calorie diets with varying amount of dietary fats on inflammation}

Weight loss lowers the risk for developing cardiovascular diseases, but sustained weight loss is difficult to achieve. In this context, dietary approach is needed. The effect of restricted diets with varying amount of dietary fats on low grade inflammation is uncertain. Sharman and Volek [84] conducted a 6-week crossover dietary intervention with reduced energy diets (low fat vs very low carbohydrate (VLCKD), $1500 \mathrm{kcal}$ ) in 15 overweight men (Table 4). A low level of ketosis was ascertained as an indication of compliance. Plasma TNF- $\alpha$, IL-6, hsCRP and sICAM-1 concentrations did not differ between diets but appreciably reduced compared with baseline. Forsythe et al. [85] conducted a parallel study with longer period dietary intervention (12-week) in a group of overweight individuals with dyslipidemia. Similar weight reduction was achieved in a longer period of time as compared with Sharman and Voleks [84]. The study reported that both diets significantly decreased concentrations of several pro-inflammatory cytokines but profound alterations were observed after VLCKD intervention as evident by remarkable decrease in an array of markers (TNF- $\alpha$, IL-6, IL-8, MCP-1, E-selectin, sICAM and plasminogen activator inhibitor-1 (PAI-1)). The authors suggested that the lower inflammatory response in VLCKD may be correlated with the increased plasma n-6 PUFA levels attributed by a higher saturated fat intake. However, the higher weight loss achieved by VLCKD group may also contribute to a more remarkable improvement in inflammatory status. 
Table 3 Chronic effects of the type of dietary fats on low grade inflammation in obese or overweight individuals

\begin{tabular}{|c|c|c|c|c|c|}
\hline Subjects: $n$ (F/M) & Design & Dietary intervention & Inflammatory response & Remarks & References \\
\hline \multirow[t]{3}{*}{$\begin{array}{l}\text { Overweight/ } \\
\text { obese: } 14 \text { (14/-) }\end{array}$} & \multirow[t]{3}{*}{$\begin{array}{l}\text { Crossover; } \\
\text { 3-week, } 1 \\
\text { week } \\
\text { wash-out }\end{array}$} & $\begin{array}{l}\text { PUFA } \\
40 \% \text { en total fat ( } 25 \% \text { en PUFA, } \\
8.5 \% \text { en SFA) } \\
\text { Fat from vegetable sources }\end{array}$ & $\begin{array}{l}\text { CRP: PUFA } \downarrow \text { vs baseline } \\
\text { IL-18: NS vs baseline }\end{array}$ & $\begin{array}{l}\text { Small sample size } \\
\text { Dyslipidemic and } \\
\text { postmenopausal women } \\
\text { were recruited }\end{array}$ & \multirow[t]{3}{*}[74]{} \\
\hline & & $\begin{array}{l}\text { SFA } \\
42 \% \text { en total fat ( } 29 \% \text { en SFA, } \\
3 \% \text { en PUFA) } \\
\text { Dairy and animal fats }\end{array}$ & \multirow[t]{2}{*}{$\begin{array}{l}\text { *No comparison was } \\
\text { made between diets }\end{array}$} & \multirow[t]{2}{*}{ Short dietary intervention } & \\
\hline & & $\begin{array}{l}\text { Iso-caloric diet ( } 2738 \mathrm{kcal} \text { ) with } \sim 21 \% \\
\text { en exchange between PUFA and SFA }\end{array}$ & & & \\
\hline \multirow[t]{3}{*}{$\begin{array}{l}\text { Abdominally overweight: } \\
61 \text { (gender not specified) } \\
\text { n-6 PUFA:32 SFA: } 29\end{array}$} & \multirow[t]{3}{*}{$\begin{array}{l}\text { Parallel; } \\
\text { 10-week }\end{array}$} & $\begin{array}{l}\text { n-6 PUFA } \\
40 \% \text { en total fat (10\% en SFA, } \\
13.5 \% \text { en LA) } \\
\text { Scones (baked using sunflower oil), } \\
\text { margarine, sunflower oil and } \\
\text { sunflower seeds }\end{array}$ & \multirow[t]{3}{*}{$\begin{array}{l}\text { IL-1RA, TNF-R2: } n-6 \\
\text { PUFA } \downarrow \text { vs SFA } \\
\text { CRP, IL-6, IL-1 } \beta \text { and } \\
\text { IL-10: NS }\end{array}$} & $\begin{array}{l}\text { Subjects used } \\
\text { antihypertensive and lipid } \\
\text { lowering drugs. }\end{array}$ & \multirow[t]{3}{*}[75]{} \\
\hline & & $\begin{array}{l}\text { SFA } \\
40 \% \text { en total fat ( } 20 \% \text { en SFA, } \\
4 \% \text { en LA) } \\
\text { Scones (baked using butter), butter } \\
\text { and butter }\end{array}$ & & \multirow[t]{2}{*}{$\begin{array}{l}\text { Low compliance: } n-6 \text { PUFA } \\
\text { diet }(n=27) ; \text { SFA diet }(n=19)\end{array}$} & \\
\hline & & $\begin{array}{l}\text { Iso-caloric diet ( } 2000 \mathrm{kcal} \text { ) consisted } \\
\text { with 10\% en exchange between n- } 6 \\
\text { PUFA and SFA. Key fat sources were } \\
\text { provided }\end{array}$ & & & \\
\hline $\begin{array}{l}\text { Overweight and } \\
\text { obese: } 76(63 / 13) \\
\text { Krill: } 25(22 / 3) \\
\text { Menhaden: } 26(21 / 5) \\
\text { Control:25 (20/5) }\end{array}$ & $\begin{array}{l}\text { Parallel; } \\
\text { 4-week }\end{array}$ & $\begin{array}{l}\text { Krill oil: } 90 \text { mg DHA + } 216 \text { mg EPA } \\
\text { Menhaden oil: } 178 \text { mg DHA + } \\
212 \text { mg EPA } \\
\text { Control: } 2 \text { g olive oil } \\
4 \times 500 \text { mg capsules/day for each } \\
\text { supplementation }\end{array}$ & hsCRP: NS & $\begin{array}{l}\text { Habitual diet was not } \\
\text { controlled }\end{array}$ & {$[78]$} \\
\hline $\begin{array}{l}\text { Sedentary } \\
\text { overweight: } \\
138(93 / 45)\end{array}$ & \multirow[t]{2}{*}{$\begin{array}{l}\text { Parallel: } \\
\text { 4-month }\end{array}$} & $\begin{array}{l}\text { n-3 PUFA: } 2.5 \mathrm{~g} / \text { dayFish oil } \\
(6 \times 500 \mathrm{mg} \text { capsules/d); EPA:DHA } \\
\text { ratio is } 7: 1\end{array}$ & \multirow[t]{2}{*}{$\begin{array}{l}\text { TNF-a, IL-6: both doses } \downarrow \\
\text { vs placebo; NS }\end{array}$} & \multirow[t]{2}{*}{$\begin{array}{l}\text { Calorie and fatty acid } \\
\text { composition of habitual } \\
\text { diets were not standardized }\end{array}$} & \multirow[t]{2}{*}[79]{} \\
\hline $\begin{array}{l}\text { n-3 PUFA } 2.5 \text { g/day: } \\
\text { 46 (29/17) } \\
\text { n-3 PUFA: } 1.25 \text { g/day: } \\
\text { 46 (28/18) } \\
\text { Placebo: } 46(36 / 10)\end{array}$ & & $\begin{array}{l}\text { n-3 PUFA: } 1.25 \mathrm{~g} / \text { day } \\
\text { Placebo: } 3 \mathrm{~g} \\
\text { Mixture of palm, olive, soy, canola } \\
\text { and cocoa butter oils; (SFA:MUFA: } \\
\text { PUFA ratio = 37:42:21) }\end{array}$ & & & \\
\hline \multirow[t]{3}{*}{$\begin{array}{l}\text { Severely obese: } \\
55 \text { (46/9) } \\
\text { n-3 PUFA: } 27(23 / 4) \\
\text { Control: } 28(23 / 5)\end{array}$} & \multirow[t]{3}{*}{$\begin{array}{l}\text { Parallel: } \\
\text { 8-week }\end{array}$} & $\begin{array}{l}\text { n-3 PUFA: } 4 \times 1 \mathrm{~g} \text { capsules/day } \\
(3.36 \mathrm{~g} \text { EPA }+ \text { DHA) } \\
\text { Control: } 5 \mathrm{~g} \text { butterfat }\end{array}$ & $\begin{array}{l}\text { IL-6: n-3 PUFA } \downarrow \\
\text { hSCRP: NS }\end{array}$ & \multirow[t]{5}{*}{$\begin{array}{l}30 \text { subjects used } \\
\text { supplementary medication } \\
\text { such as antihypertension and } \\
\text { proton pump inhibitors } \\
\text { Incomplete dietary records }\end{array}$} & \multirow[t]{3}{*}{ [82] } \\
\hline & & $\begin{array}{l}\text { Iso-caloric diet consisted of 30\% } \\
\text { en fat, } 15 \% \text { protein and } 55 \% \\
\text { en carbohydrate }\end{array}$ & $\begin{array}{l}\text { SAT gene expression of } \\
\text { CCL2, CCL3, H1F1A and } \\
\text { TGFB1: } n-3 \text { PUFA } \downarrow\end{array}$ & & \\
\hline & & & $\begin{array}{l}\text { EPA- and DHA-derived } \\
\text { eicosanoids synthesis in } \\
\text { SAT and VAT: } n-3 \text { PUFA } \uparrow\end{array}$ & & \\
\hline $\begin{array}{l}\text { Abdominally } \\
\text { overweight/ obese: } \\
51(40 / 11)\end{array}$ & \multirow[t]{2}{*}{$\begin{array}{l}\text { Parallel: } \\
\text { 8-week }\end{array}$} & $\begin{array}{l}\text { ALA: } 11 \mathrm{~g} / \text { day flaxseed oil } \\
\text { Control: habitual diet }\end{array}$ & IL-6, TNF-a, CRP: NS & & \multirow[t]{2}{*}{ [83] } \\
\hline $\begin{array}{l}\text { ALA: } 27(21 / 6) \\
\text { Control: } 24(19 / 5)\end{array}$ & & $\begin{array}{l}\text { Iso-caloric diet ( } 2000 \mathrm{kcal}) \text { with a } \\
\text { balance of SFA and MUFA intake }\end{array}$ & & & \\
\hline
\end{tabular}

\% en, percentage energy; IL-1RA, interleukin-1 receptor antagonist; TNF-R2, tumor necrosis factor- receptor 2; hsCRP, high-sensitivity C-reactive protein; IL, interleukin; TNF-a, tumor necrosis factor- alpha; ALA, alpha linolenic acid; SFA, saturated fats; MUFA, monounsaturated fats; PUFA, polyunsaturated fats; DHA, docosahexaenoic acid; EPA, eicosapentaenoic acid; VAT, visceral adipose tissue; SAT, subcutaneous adipose tissue; CCL, chemokine (C-C) motif ligand; HIF1A, hypoxia-inducible factor 1-alpha; TGFB1, transforming growth factor $\beta 1$; NS, no significant difference between diets; $\downarrow$, reduced concentrations; $\uparrow$, increased concentrations. 
Table 4 Chronic effects of restricted calorie diets with varying amount of fats on low grade inflammation in obese and overweight individuals

\begin{tabular}{|c|c|c|c|c|c|}
\hline $\begin{array}{l}\text { Subjects: } n \\
\text { (F/M) }\end{array}$ & Design & Dietary intervention & Inflammatory response & Remarks & References \\
\hline \multirow[t]{2}{*}{$\begin{array}{l}\text { Overweight: } \\
15(-/ 15)\end{array}$} & \multirow[t]{2}{*}{$\begin{array}{l}\text { Crossover: } \\
\text { 6-week }\end{array}$} & $\begin{array}{l}\text { VLCKD } 60 \% \text { en total fat, } 10 \% \text { en CHO, } 30 \% \text { en protein } \\
\text { Unlimited type of fat or cholesterol amount } \\
\text { from sources such as beef, poultry, fish, oils, various } \\
\text { nuts/seeds, moderate amount of vegetables, salads } \\
\text { with low-carbohydrate dressings, moderate amount } \\
\text { of cheese, eggs, protein powder, water/ low-carbohydrate } \\
\text { diet drinks, low-carbohydrate bars and shakes } \\
{ }^{*} \text { Customied diabetic exchange lists were used. }\end{array}$ & $\begin{array}{l}\text { TNF-a, IL-6, hsCRP, sICAM-1: both } \\
\text { VLCKD \& LFD } \downarrow \text { vs baseline: NS } \\
\text { sP-sel: NS } \\
\text { Body weight: VLCKD } \downarrow 6.5 \mathrm{~kg} \text {, } \\
\text { LFD } \downarrow 3.7 \mathrm{~kg}\end{array}$ & \multirow[t]{2}{*}{$\begin{array}{l}\text { Protein intake } \\
\text { not standardised } \\
\text { across diets }\end{array}$} & \multirow[t]{2}{*}[84]{} \\
\hline & & $\begin{array}{l}\text { LFD } 25 \% \text { en fat, } 55 \% \text { en CHO, } 20 \% \text { en protein } \\
(<10 \% \text { SFA, }<300 \mathrm{mg} \text { cholesterol) }\end{array}$ & & & \\
\hline \multirow[t]{2}{*}{ Overweight: 20} & \multirow[t]{2}{*}{$\begin{array}{l}\text { Parallel: } \\
\text { 12-week }\end{array}$} & $\begin{array}{l}\text { VLCKD } \\
60 \% \text { en fat } 10 \% \text { en CHO } 30 \% \text { en protein } \\
\text { Unlimited amount of beef, poultry, fish, eggs, oils } \\
\text { and heavy creams; moderate amount of hard } \\
\text { cheeses, low-carbohydrate vegetables and salad } \\
\text { dressings; small amount of nuts, nut butters } \\
\text { and seeds. }\end{array}$ & $\begin{array}{l}\text { TNF- } a \text {, IL-8, MCP-1, E-selectin, } \\
\text { SICAM- } 1 \text { PAI-1: both VLCKD \& } \\
\text { LFD } \downarrow \text { vs baseline; VLKCD } \downarrow \downarrow \\
\text { IL-6, CRP, VEGF, P-sel, EGF and } \\
\text { sVCAM- }- \text { : both VLCKD \& LFD } \downarrow \\
\text { vs baseline; NS }\end{array}$ & \multirow[t]{2}{*}{$\begin{array}{l}\text { Protein intake } \\
\text { not standardised } \\
\text { across diets } \\
\text { Dyslipidemic } \\
\text { subjects were } \\
\text { included }\end{array}$} & \multirow[t]{2}{*}{ [85] } \\
\hline & & $\begin{array}{l}\text { LFD } \\
25 \% \text { en fat, } 55 \% \text { en } \mathrm{CHO}, 20 \% \text { en protein }(<10 \% \\
\text { SFA, < } 300 \mathrm{mg} \text { cholesterol) } \\
\text { Whole grains (bread, cereals and pastas), fruit/fruit } \\
\text { juices, vegetables, vegetables oils, low at dairy, and } \\
\text { lean meat products } \\
\text { *Standard diabetic exchange lists were used. }\end{array}$ & $\begin{array}{l}\text { Body weight: VLCKD } \downarrow 5.6 \mathrm{~kg} \text {, } \\
\text { LFD } \downarrow 3.7 \mathrm{~kg}\end{array}$ & & \\
\hline
\end{tabular}

VLCKD, very low carbohydrate ketogenic diet; LFD, low fat diet; CHO, carbohydrate; \% en, percentage energy; SFA, saturated fats; TNF-a, tumor necrosis factor- alpha; IL, interleukin; hsCRP, high-sensitivity C-reactive protein; sICAM-1, soluble intracellular adhesion molecule-1; SP-sel, soluble P-selectin; MCP-1, monochemoattractant protein-1; PAI-1, plasminogen activator inhibitor-1; VEGF, vascular endothelial growth factor; EGF, epidermal growth factor; sVCAM-1, soluble vascular adhesion molecule-1; NS, no significant difference between diets; $\downarrow$, reduced concentrations; $\downarrow \downarrow$, greater reduction compared to the other diets.

\section{Restricted calorie diets with varying type of dietary fats on inflammation}

In recent years, the effect of n-3 PUFA on weight loss has been studied extensively. Four studies have been identified in this respect (Table 5). Munro and Garg [86] reported that a low energy diet combined with n-3 PUFA (8\% en of total fat intake, $0.42 \mathrm{~g} \mathrm{EPA}+1.62 \mathrm{~g}$ DHA from fish oil) or control (MUFA, sunola oil) for 12-week did not differ on plasma adiponectin, leptin, hsCRP and IL- 6 concentrations. A significant weight loss was achieved and a 2 -fold increase in plasma EPA and DHA suggested compliance. Nevertheless, Kratz et al. [87] provided 16 women and 10 men a diet rich in $n-3$ PUFA (3.5\% en of total fat intake, from both plant and marine sources) or a control diet (3.2\% en intake from MUFA) for a consecutive 2-week lead-in followed by a 2 -week iso-caloric period and a 12-week ad libitum period. Weight loss resulted in an expected increase in adiponectin levels during the ad libitum period. Both n-3 PUFA and control diets however did not alter plasma adiponectin levels. The authors discussed that the dose of fish oil provided $(725 \mathrm{mg})$ is equivalent to the amount of $125-250 \mathrm{~g}$ fatty fish/day, which is on the higher end of human consumption.

Two similar studies were conducted to compare the effects of n-3 PUFA (1.1 g/day n-3 PUFA with $0.6 \mathrm{~g}$
EPA, 0.5 g DHA) and MUFA (control, high oleic sunflower oil) supplementation $v s$ weight loss on inflammatory biomarkers in 11 healthy moderately obese men $[5,6]$. The subjects consumed a succession of very low calorie diet for 4-week, followed by a 2 -week restricted calorie diet and a 2-week weight sustained diet. At the end of dietary intervention, fasting blood samples were collected followed by a $4 \mathrm{~h}$ postprandial high fat challenge (50 $\mathrm{g}$ fat with 2:2:1 ratio of SFA:MUFA:PUFA). Weight loss $(\sim 9.4 \mathrm{~kg})$ reduced both fasting and postprandial sICAM, hsCRP and postprandial IL-6, sTNFR55, sTNF-R75 and PAI-1 antigen. MCP-1 was lowered by both n-3 PUFA and weight loss. Hence, weight loss rather than $n-3$ PUFA supplementation had prominent impact on low grade inflammation.

\section{Strengths and limitations}

The current evidence provides insight on the influence of amount and type of dietary fats on inflammatory response in both acute and chronic dietary intervention studies in obese and overweight individuals. The present review is not a systematic review with grading tools applied, however the limited evidence in hand suggests that dietary fats may play a pivotal role in modulating low grade inflammation in a potentially vulnerable group of population to disease progression. However, the 
Table 5 Chronic effects of restricted calorie diets with varying type of fats on low grade inflammation in obese and overweight individuals

\begin{tabular}{|c|c|c|c|c|c|}
\hline $\begin{array}{l}\text { Subjects: } n \\
\text { (F/M) }\end{array}$ & Design & Dietary intervention & $\begin{array}{l}\text { Inflammatory } \\
\text { response }\end{array}$ & Remarks & References \\
\hline $\begin{array}{l}\text { Overweight: } \\
33(22 / 11)\end{array}$ & Parallel: 12-week & $\begin{array}{l}\text { n-3 PUFA: } 6 \text { capsules of } 1 \mathrm{~g} \text { fish oil daily } \\
(0.42 \mathrm{~g} \text { EPA }+1.62 \mathrm{~g} \text { DHAVd })\end{array}$ & $\begin{array}{l}\text { Body weight: } n-3 \text { PUFA } \\
\downarrow 4.2 \mathrm{~kg} \text {, placebo } \downarrow \\
3.17 \mathrm{~kg} ; \mathrm{NS}\end{array}$ & & [86] \\
\hline $\begin{array}{l}n-3 \text { PUFA: } \\
15(10 / 5)\end{array}$ & & $\begin{array}{l}\text { Placebo (MUFA): } 6 \text { capsules of } 1 \text { gunola oil } \\
\text { daily }\end{array}$ & $\begin{array}{l}\text { Leptin, adiponectin, } \\
\text { hsCRP, IL-6: NS }\end{array}$ & & \\
\hline
\end{tabular}

Overweight: Parallel: 14-week $26(16 / 10)$

$\begin{array}{ll}\text { n-3 PUFA: } & \text { Phase 1: 2-week } \\ \text { 13 (8/5) } & \text { Phase 2: 2-week } \\ \text { control: } & \text { Phase 3:12-week }\end{array}$

$13(8 / 5)$

\begin{tabular}{|c|c|}
\hline $\begin{array}{l}\text { Obese: } \\
11(-/ 11)\end{array}$ & Cross-over \\
\hline Phase 1: & Phase 1: 6-week \\
\hline $11(-/ 11)$ & Phase 2: 8-week \\
\hline Phase 2: & (very low calorie diet, 4-week; \\
\hline $8(-/ 8)$ & $\begin{array}{l}\text { restricted energy diet, 2-week; } \\
\text { weight sustained diet, 2-week) }\end{array}$ \\
\hline
\end{tabular}

Obese: Cross-over

$11(-/ 11)$

Postprandial challenges at the
Daily intake were $5000 \mathrm{~kJ}$ for female and $6000 \mathrm{~kJ}$ for males with $\sim 30 \%$ en total fat intake

Phase 1 (lead-in):

$34.3 \%$ en fat (4.8\% en $n-6,0.5 \%$ en $n-3$ PUFA)

Both n-3 PUFA and control groups consumed the same diet

Phase 2 (iso-caloric, 1800 kcal)): n-3 PUFA: 12 capsules of $725 \mathrm{mg}$ fish oil (2.88 g n-3 PUFA)

$34.7 \%$ en fat (n-6 PUFA, $4.9 \%$ en, $n-3$ PUFA, 3.6\% en)

Main source of n-3 PUFAs: canola and flaxseed oils, and margarines rich in ALA

Control: high oleic sunflower oil capsules $34.3 \%$ en total fat $(4.8 \%$ en $n-6,0.5 \%$ en n-3 PUFA)

Main source of oils: high oleic safflower and sunflower oils, and margarines based on these oils

\section{Phase 3 (ad libitum):}

$115 \%$ of the amount of food provided in phase 1 and 2

Phase 1 (fish oil study): n-3 PUFA: $0.6 \mathrm{~g}$ EPA + $0.5 \mathrm{~g}$ DHA

Control: 6 capsules 500 mg of high oleic sunflower oil with ad-libitum Dutch diet

No fish consumption is allowed

Phase 2 (weight loss period): Very low calorie diet: $480 \mathrm{kcal} /$ day with shakes $+250 \mathrm{~g}$ vegetables and fruits except banana end of each intervention: 0, 2, 4 h

Restricted energy diet: $1000 \mathrm{kcal} /$ day with mixed solid energy-restricted diet with a recommended composition

Weight sustained diet: Diet at commensurate calories to maintain the newly achieved weights Postprandial meals: $50.1 \mathrm{~g}$ fat, milkshake

Phase 1 (fish oil study): n-3 PUFA: $0.6 \mathrm{~g}$ EPA + $0.5 \mathrm{~g}$ DHA
TNF-a: n-3 PUFA $\downarrow$ vs

baseline; NS

Body weight after Phase 3:

Both diets $\downarrow(\sim 3.5 \%$

body weight); NS

Adiponectin: both diets $\uparrow$ vs baseline; NS HMW adiponectin: NS

\section{Postprandial}

IL-6, CRP, sTNF-R55,

Small sample size STNF-R75, PAl-1 antigen: weight loss $\downarrow$ : NS TNF-a: NS

$\begin{array}{ll}\text { Fasting } & \text { Small } \\ \text { sICAM-1, hsCRP: weight } & \text { sample } \\ \text { loss } \downarrow \text {; NS } & \text { size } \\ \text { SE-sel, MCP-1: NS } & \end{array}$




\section{Table 5 Chronic effects of restricted calorie diets with varying type of fats on low grade inflammation in obese and overweight individuals (Continued)}

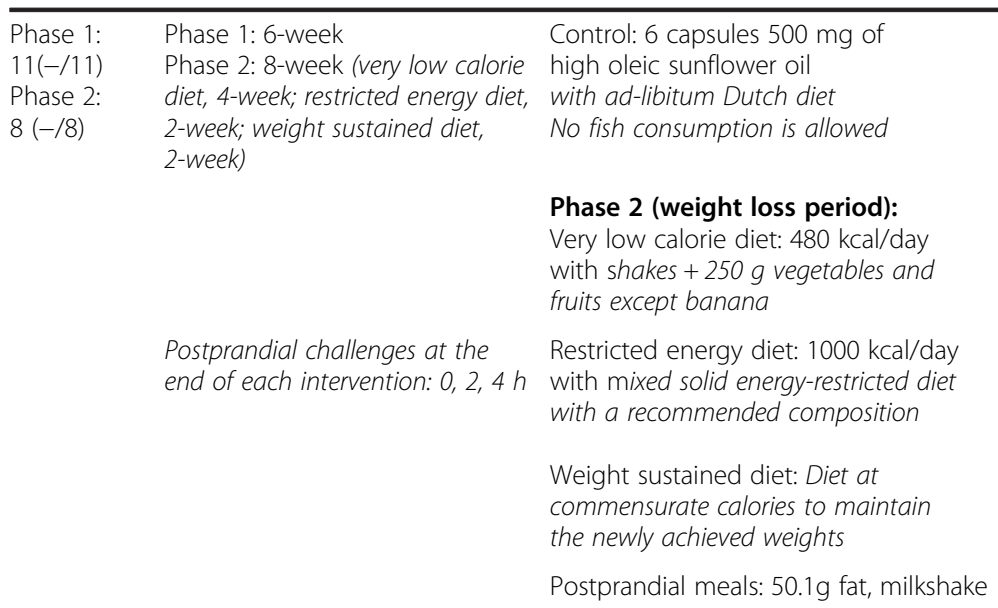

\% en, percentage energy; DHA, docosahexaenoic acid; EPA, eicosapentaenoic acid; HMW, high molecular weight; MUFA, monounsaturated fats; PUFA, polyunsaturated fats; hsCRP, high-sensitivity C-reactive protein; IL, interleukin; PAI-1, plasminogen activator inhibitor-1; sTNF-R55, soluble tumor necrosis factor receptor 55; sTNF-R75, soluble tumor necrosis factor receptor 75; sICAM-1, soluble intracellular adhesion molecule-1; sE-sel, soluble E-selectin; MCP-1, monochemoattractant protein-1; NS, no significant difference between diets; $\downarrow$, reduced concentrations; $\uparrow$, increased concentrations.

diverting information generated so far highlights the need for better designed dietary intervention in order to unravel the crucial role of fatty acids on low grade inflammation. Most of the studies reported are underpowered hence reflecting variations which may mask the true effects of dietary treatment. In addition, the comparisons made were based on dietary fats as a whole rather than a head-to-head comparison of individual fatty acid per se. The results generated thus may not be extrapolated to individual fatty acid. In addition, the source of dietary fats whether from animal or vegetable origin may generate remarkable varying findings. This is in particular obvious when palm oil was used as SFA instead of butter or cream as discussed. The physical characteristics such as solid fat content or melting point have been reported to produce discernable outcome on postprandial lipemia [88]. Furthermore, population difference is another concern to be noted. The subjects recruited ranging from healthy overweight to severely obese with mildly elevated dyslipidemia, young to elder women to men may generate differing outcome. For acute studies in particular, the minimum amount of fat required to induce a remarkable postprandial inflammatory response is $50 \mathrm{~g}$ [65]. The composition of test meals i.e. mixed meal $v s$ milk shake may generate differing outcome which may complicate data interpretation. The selection of control meal may also affect the results generated. Furthermore, proper blood sampling time point and procedure may greatly influence the detection of postprandial changes. Collective information has suggested that lower plasma IL-6 levels were observed at 1 hour after high fat meals, the missing time point may lead to different outcome [63,64].

\author{
Postprandial sICAM \\ hsCRP: weight loss $\downarrow$ \\ MCP1: PUFA \& weight \\ loss $\downarrow$ \\ sel: NS
}

Furthermore, diverting observation was obtained when different methods of blood sampling were used. It was reported that cannula rather than indwelling catheter causes minimal changes in plasma IL-6 [89]. However this may not be practical for study involving multiple blood samplings. The existing data on chronic studies highlights the need for proper designed studies. Most of the previous studies reported information on the intake of dietary fat using self-reporting dietary records. The major pitfall of dietary recall is the underestimation of dietary intake and lack of validation of methodology used [90]. In addition, the duration of dietary intervention in order to detect significant changes and dosage applied may also lead to inconsistency of findings. Taken together, future studies addressing these issues may provide more reliable and conclusive evidence on the role of dietary fatty acids on low grade inflammation.

\section{Conclusion}

High fat meal may provoke inflammatory response in a postprandial state however the effect of type of dietary fats remained uncertain. Dietary fats, in particular n-3 PUFA may play a pivotal role in improving inflammatory status in severely obese individuals, however the impact may be marginal compared with weight loss. No conclusive evidence on the effect of type of dietary fatty acids on varying cytokines. A complete understanding on the role of dietary fatty acids on low grade inflammation merits further investigation. Information is needed based on rigorously well designed clinical studies. 


\section{Abbreviations}

SFA: Saturated fats; PUFA: Polyunsaturated fats; DHA: Docosahexaenoic acid; EPA: Eicosapentaenoic acid; TAG: Triacylglycerols; TNF-a: Tumor necrosis factor- alpha; IL-6: Interleukin-6; MCP-1: Monochemoattractant protein-1; CCR2: CC chemokine receptor 2; IL-10: Interleukin-10; IL-1Ra: Interleukin-1 receptor antagonist; JNK: Jun N-terminal kinase; NF-KB: Nuclear factor-kappa B; PBMC: Peripheral blood mononuclear cells; TLR: Toll-like receptor; ROS: Reactive oxygen species; LA: Linoleic acid; AA: Arachidonic acid; PGE : Prostaglandin E2; ALA: Alpha linolenic acid; hsCRP: High-sensitivity C-reactive protein; SICAM-1: Soluble intracellular adhesion molecule-1; SVCAM-1: Soluble vascular adhesion molecule-1; MUFA: Monounsaturated fats; PAl-1: Plasminogen activator inhibitor-1.

\section{Competing interests}

TKT and KN are providing consulting services to the Malaysian Palm Oil Board (MPOB). No potential conflict of interest was reported by CCY and CLF.

\section{Authors' contributions}

TKT, CCY and CLF contributed to the conception and design of the review as well as drafting. CCY, TKT and CLF performed the literature search. TKT and $\mathrm{KN}$ revised the manuscript. All authors read and approved the final manuscript.

\section{Authors' information}

TKT is a PhD graduate, and research officer at the Malaysian Palm Oil Board (MPOB). CLF is a postgraduate PhD student and CCY is a postgraduate master student, at University of Malaya. KN is a PhD graduate, and serves as a minister at the Embassy of Malaysia and Mission of Malaysia to the European Union.

\section{Author details}

${ }^{1}$ Product Development and Advisory Services, Malaysian Palm Oil Board (MPOB), 6 Persiaran Institusi, Bandar Baru Bangi, 43000 Kajang, Selangor, Malaysia. ${ }^{2}$ Department of Molecular Medicine, Faculty of Medicine, University of Malaya, 50603 Kuala Lumpur, Malaysia. ${ }^{3}$ Department of Medicine, Faculty of Medicine, University of Malaya, 50603 Kuala Lumpur, Malaysia.

Received: 12 April 2013 Accepted: 13 January 2014

Published: 29 January 2014

\section{References}

1. Flegal KM, Carroll MD, Kit BK, Ogden CL: Prevalence of obesity and trends in the distribution of body mass index among US adults, 1999-2010. JAMA 2012, 307:491-497.

2. Olson NC, Callas PW, Hanley AJ, Festa A, Haffner SM, Wagenknecht LE, Tracy RP: Circulating levels of TNF-alpha are associated with impaired glucose tolerance, increased insulin resistance, and ethnicity: the insulin resistance atherosclerosis study. J Clin Endocrinol Metab 2012, 97:1032-1040.

3. Bose KS, Gupta SK, Vyas P: Adipocytokine levels in genetically high risk for type 2 diabetes in the Indian population: a cross-sectional study. Exp Diabetes Res 2012, 2012:386524.

4. Gelaye B, Revilla L, Lopez T, Suarez L, Sanchez SE, Hevner K, Fitzpatrick AL, Williams MA: Association between insulin resistance and c-reactive protein among Peruvian adults. Diabetol Metab Syndr 2010, 2:30

5. Jellema A, Plat J, Mensink RP: Weight reduction, but not a moderate intake of fish oil, lowers concentrations of inflammatory markers and PAl-1 antigen in obese men during the fasting and postprandial state. Eur J Clin Invest 2004, 34:766-773.

6. Plat J, Jellema A, Ramakers J, Mensink RP: Weight loss, but not fish oil consumption, improves fasting and postprandial serum lipids, markers of endothelial function, and inflammatory signatures in moderately obese men. J Nutr 2007, 137:2635-2640.

7. Kien CL: Dietary interventions for metabolic syndrome: role of modifying dietary fats. Curr Diab Rep 2009, 9:43-50.

8. Montell E, Turini M, Marotta M, Roberts M, Noe V, Ciudad CJ, Mace K, Gomez-Foix AM: DAG accumulation from saturated fatty acids desensitizes insulin stimulation of glucose uptake in muscle cells. Am J Physiol Endocrinol Metab 2001, 280:E229-E237.

9. Chavez JA, Summers SA: Characterizing the effects of saturated fatty acids on insulin signaling and ceramide and diacylglycerol accumulation in 3 T3-L1 adipocytes and C2C12 myotubes. Arch Biochem Biophys 2003, 419:101-109.

10. Wang Z, Liu D, Wang F, Liu S, Zhao S, Ling EA, Hao A: Saturated fatty acids activate microglia via Toll-like receptor 4/NF-kappaB signalling. Br J Nutr 2012, 107:229-241.

11. Alvheim AR, Torstensen BE, Lin YH, Lillefosse HH, Lock EJ, Madsen L, Hibbeln JR, Malde MK: Dietary linoleic acid elevates endogenous 2-arachidonoylglycerol and anandamide in Atlantic salmon (Salmo salar L.) and mice, and induces weight gain and inflammation in mice. Br J Nutr 2012, 109:1508-1517.

12. Todoric J, Loffler M, Huber J, Bilban M, Reimers M, Kadl A, Zeyda M, WaldhausI W, Stulnig TM: Adipose tissue inflammation induced by high-fat diet in obese diabetic mice is prevented by $n-3$ polyunsaturated fatty acids. Diabetologia 2006, 49:2109-2119.

13. Kalupahana NS, Claycombe K, Newman SJ, Stewart T, Siriwardhana N, Matthan N, Lichtenstein AH, Moustaid-Moussa N: Eicosapentaenoic acid prevents and reverses insulin resistance in high-fat diet-induced obese mice via modulation of adipose tissue inflammation. J Nutr 2010, 140:1915-1922.

14. Vijay-Kumar M, Vanegas SM, Patel N, Aitken JD, Ziegler TR, Ganji V: Fish oil rich diet in comparison to saturated fat rich diet offered protection against lipopolysaccharide-induced inflammation and insulin resistance in mice. Nutr Metab (Lond) 2011, 8:16.

15. Patel C, Ghanim H, Ravishankar S, Sia CL, Viswanathan P, Mohanty P, Dandona $\mathrm{P}$ : Prolonged reactive oxygen species generation and nuclear factor-kappaB activation after a high-fat, high-carbohydrate meal in the obese. J Clin Endocrinol Metab 2007, 92:4476-4479.

16. Manning PJ, Sutherland WH, McGrath MM, de Jong SA, Walker RJ, Williams MJ: Postprandial cytokine concentrations and meal composition in obese and lean women. Obesity (Silver Spring) 2008, 16:2046-2052.

17. Maury E, Brichard SM: Adipokine dysregulation, adipose tissue inflammation and metabolic syndrome. Mol Cell Endocrinol 2010, 314:1-16.

18. Jo J, Gavrilova O, Pack S, Jou W, Mullen S, Sumner AE, Cushman SW, Periwal V: Hypertrophy and/or Hyperplasia: dynamics of adipose tissue growth. PLoS Comput Biol 2009, 5:e1000324.

19. Anghel SI, Wahli W: Fat poetry: a kingdom for PPAR gamma. Cell Res 2007, 17:486-511.

20. Vachharajani V, Granger DN: Adipose tissue: a motor for the inflammation associated with obesity. IUBMB Life 2009, 61:424-430.

21. Weisberg SP, McCann D, Desai M, Rosenbaum M, Leibel RL, Ferrante AW Jr: Obesity is associated with macrophage accumulation in adipose tissue. J Clin Invest 2003, 112:1796-1808.

22. de Luca C, Olefsky JM: Inflammation and insulin resistance. FEBS Lett 2008, 582:97-105.

23. Lumeng $C N$, Bodzin $J$, Saltiel AR: Obesity induces a phenotypic switch in adipose tissue macrophage polarization. J Clin Invest 2007, 117:175-184.

24. Prieur X, Mok CY, Velagapudi VR, Nunez V, Fuentes L, Montaner D, Ishikawa K, Camacho A, Barbarroja N, O'Rahilly S, et al: Differential lipid partitioning between adipocytes and tissue macrophages modulates macrophage lipotoxicity and M2/M1 polarization in obese mice. Diabetes 2011, 60:797-809

25. Olefsky JM, Glass CK: Macrophages, inflammation, and insulin resistance. Annu Rev Physiol 2010, 72:219-246.

26. Kalupahana NS, Claycombe KJ, Moustaid-Moussa N: (n-3) Fatty acids alleviate adipose tissue inflammation and insulin resistance: mechanistic insights. Adv Nutr 2011, 2:304-316

27. Ajuwon KM, Spurlock ME: Palmitate activates the NF-kappaB transcription factor and induces IL- 6 and TNFalpha expression in 3 T3-L1 adipocytes. J Nutr 2005, 135:1841-1846.

28. Bradley RL, Fisher FF, Maratos-Flier E: Dietary fatty acids differentially regulate production of TNF-alpha and IL-10 by murine 3T3-L1 adipocytes. Obesity (Silver Spring) 2008, 16:938-944.

29. Wang X, Cheng M, Zhao M, Ge A, Guo F, Zhang M, Yang Y, Liu L, Yang N: Differential effects of high-fat-diet rich in lard oil or soybean oil on osteopontin expression and inflammation of adipose tissue in diet-induced obese rats. Eur J Nutr 2013, 52:1181-1189.

30. Takeda K, Kaisho T, Akira S: Toll-like receptors. Annu Rev Immunol 2003, 21:335-376

31. Kim JJ, Sears DD: TLR4 and insulin resistance. Gastroenterol Res Pract 2010 2010:11. Article ID212563.

32. Amyot J, Semache M, Ferdaoussi M, Fontes G, Poitout V: Lipopolysaccharides impair insulin gene expression in isolated islets of 
Langerhans via Toll-Like Receptor-4 and NF-kappaB signalling. PLoS One 2012, 7:e36200.

33. Saberi M, Woods NB, de Luca C, Schenk S, Lu JC, Bandyopadhyay G, Verma IM, Olefsky JM: Hematopoietic cell-specific deletion of toll-like receptor 4 ameliorates hepatic and adipose tissue insulin resistance in high-fat-fed mice. Cell Metab 2009, 10:419-429.

34. Lee JY, Ye J, Gao Z, Youn HS, Lee WH, Zhao L, Sizemore N, Hwang DH: Reciprocal modulation of Toll-like receptor-4 signaling pathways involving MyD88 and phosphatidylinositol 3-kinase/AKT by saturated and polyunsaturated fatty acids. J Biol Chem 2003, 278:37041-37051.

35. Wong SW, Kwon MJ, Choi AM, Kim HP, Nakahira K, Hwang DH: Fatty acids modulate Toll-like receptor 4 activation through regulation of receptor dimerization and recruitment into lipid rafts in a reactive oxygen species-dependent manner. J Biol Chem 2009, 284:27384-27392.

36. Shi H, Kokoeva MV, Inouye K, Tzameli I, Yin H, Flier JS: TLR4 links innate immunity and fatty acid-induced insulin resistance. J Clin Invest 2006, 116:3015-3025.

37. Schaeffler A, Gross P, Buettner R, Bollheimer C, Buechler C, Neumeier M, Kopp A, Schoelmerich J, Falk W: Fatty acid-induced induction of Toll-like receptor-4/nuclear factor-kappaB pathway in adipocytes links nutritional signalling with innate immunity. Immunology 2008, 126:233-245.

38. Dostert C, Petrilli V, Van Bruggen R, Steele C, Mossman BT, Tschopp J: Innate immune activation through Nalp3 inflammasome sensing of asbestos and silica. Science 2008, 320:674-677.

39. Zhou R, Yazdi AS, Menu P, Tschopp J: A role for mitochondria in NLRP3 inflammasome activation. Nature 2011, 469:221-225.

40. Ting JP, Willingham SB, Bergstralh DT: NLRs at the intersection of cell death and immunity. Nat Rev Immunol 2008, 8:372-379.

41. Franchi $L$, Eigenbrod T, Munoz-Planillo R, Nunez G: The inflammasome: a caspase-1-activation platform that regulates immune responses and disease pathogenesis. Nat Immunol 2009, 10:241-247.

42. Jager J, Gremeaux T, Cormont M, Le Marchand-Brustel Y, Tanti JF: Interleukin-1 beta-induced insulin resistance in adipocytes through down-regulation of insulin receptor substrate-1 expression. Endocrinology 2007, 148:241-251

43. Wen $H$, Gris $D$, Lei $Y$, Jha $S$, Zhang L, Huang MT, Brickey WJ, Ting JP: Fatty acid-induced NLRP3-ASC inflammasome activation interferes with insulin signaling. Nat Immunol 2011, 12:408-415.

44. Myers $J$, Allen JC: Nutrition and Inflammation: Insight on dietary pattern, obesity and asthma. AJLM 2012, 6:14-17.

45. Calder PC: $n-3$ polyunsaturated fatty acids, inflammation, and inflammatory diseases. Am J Clin Nutr 2006, 83:1505S-1519S.

46. Iyer A, Fairlie DP, Prins JB, Hammock BD, Brown L: Inflammatory lipid mediators in adipocyte function and obesity. Nat Rev Endocrinol 2010, 6:71-82.

47. Wahli W, Michalik L: PPARs at the crossroads of lipid signaling and inflammation. Trends Endocrinol Metab 2012, 23:351-363.

48. Bonnans C, Vachier I, Chavis C, Godard P, Bousquet J, Chanez P: Lipoxins are potential endogenous antiinflammatory mediators in asthma. Am J Respir Crit Care Med 2002, 165:1531-1535

49. Itoh M, Suganami T, Satoh N, Tanimoto-Koyama K, Yuan X, Tanaka M, Kawano H, Yano T, Aoe S, Takeya M, et al: Increased adiponectin secretion by highly purified eicosapentaenoic acid in rodent models of obesity and human obese subjects. Arterioscler Thromb Vasc Biol 2007, 27:1918-1925.

50. Puglisi MJ, Hasty AH, Saraswathi V: The role of adipose tissue in mediating the beneficial effects of dietary fish oil. J Nutr Biochem 2011, 22:101-108.

51. Nakahira K, Kim HP, Geng XH, Nakao A, Wang X, Murase N, Drain PF, Sasidhar M, Nabel EG, Takahashi T, et al: Carbon monoxide differentially inhibits TLR signaling pathways by regulating ROS-induced trafficking of TLRs to lipid rafts. J Exp Med 2006, 203:2377-2389.

52. Rockett BD, Salameh M, Carraway K, Morrison K, Shaikh SR: n-3 PUFA improves fatty acid composition, prevents palmitate-induced apoptosis, and differentially modifies $B$ cell cytokine secretion in vitro and ex vivo. J Lipid Res 2010, 51:1284-1297.

53. Oh DY, Talukdar S, Bae EJ, Imamura T, Morinaga H, Fan W, Li P, Lu WJ, Watkins SM, Olefsky JM: GPR120 is an omega-3 fatty acid receptor mediating potent anti-inflammatory and insulin-sensitizing effects. Cell 2010, 142:687-698.

54. Talukdar S, Olefsky JM, Osborn O: Targeting GPR120 and other fatty acid-sensing GPCRs ameliorates insulin resistance and inflammatory diseases. Trends Pharmacol Sci 2011, 32:543-550.
55. Stulnig TM, Huber J, Leitinger N, Imre EM, Angelisova P, Nowotny $P$, WaldhausI W: Polyunsaturated eicosapentaenoic acid displaces proteins from membrane rafts by altering raft lipid composition. J Biol Chem 2001, 276:37335-37340.

56. Krebs JD, Browning LM, McLean NK, Rothwell JL, Mishra GD, Moore CS, Jebb SA: Additive benefits of long-chain $\mathrm{n}-3$ polyunsaturated fatty acids and weight-loss in the management of cardiovascular disease risk in overweight hyperinsulinaemic women. Int J Obes (Lond) 2006 30:1535-1544.

57. Neschen S, Morino K, Rossbacher JC, Pongratz RL, Cline GW, Sono S, Gillum M, Shulman Gl: Fish oil regulates adiponectin secretion by a peroxisome proliferator-activated receptor-gamma-dependent mechanism in mice. Diabetes 2006, 55:924-928.

58. Zhou XR, Sun CH, Liu JR, Zhao D: Dietary conjugated linoleic acid increases PPAR gamma gene expression in adipose tissue of obese rat, and improves insulin resistance. Growth Horm IGF Res 2008, 18:361-368

59. Gormsen LC, Nielsen C, Jessen N, Jorgensen JO, Moller N: Time-course effects of physiological free fatty acid surges on insulin sensitivity in humans. Acta Physiol (Oxf) 2011, 201:349-356.

60. Sanders TA, Filippou A, Berry SE, Baumgartner S, Mensink RP: Palmitic acid in the sn-2 position of triacylglycerols acutely influences postprandial lipid metabolism. Am J Clin Nutr 2011, 94:1433-1441.

61. Esser D, van Dijk SJ, Oosterink E, Muller M, Afman LA: A high-fat SFA, MUFA, or n3 PUFA challenge affects the vascular response and initiates an activated state of cellular adherence in lean and obese middle-aged men. J Nutr 2013, 143:843-851.

62. Phillips LK, Peake JM, Zhang X, Hickman IJ, Briskey DR, Huang BE, Simpson P, Li SH, Whitehead JP, Martin JH, Prins JB: Postprandial total and HMW adiponectin following a high-fat meal in lean, obese and diabetic men. Eur J Clin Nutr 2013, 67:377-384.

63. Blackburn P, Despres JP, Lamarche B, Tremblay A, Bergeron J, Lemieux I, Couillard C: Postprandial variations of plasma inflammatory markers in abdominally obese men. Obesity (Silver Spring) 2006, 14:1747-1754

64. Miglio C, Peluso I, Raguzzini A, Villano DV, Cesqui E, Catasta G, Toti E, Serafini M: Antioxidant and inflammatory response following high-fat meal consumption in overweight subjects. Eur J Nutr 2013, 52:1107-1114.

65. Nappo F, Esposito K, Cioffi M, Giugliano G, Molinari AM, Paolisso G, Marfella R, Giugliano D: Postprandial endothelial activation in healthy subjects and in type 2 diabetic patients: role of fat and carbohydrate meals. J Am Coll Cardiol 2002, 39:1145-1150.

66. Cruz-Teno C, Perez-Martinez P, Delgado-Lista J, Yubero-Serrano EM, Garcia-Rios A, Marin C, Gomez P, Jimenez-Gomez Y, Camargo A, RodriguezCantalejo F, et al: Dietary fat modifies the postprandial inflammatory state in subjects with metabolic syndrome: the LIPGENE study. Mol Nutr Food Res 2012, 56:854-865.

67. Masson CJ, Mensink RP: Exchanging saturated fatty acids for ( $n-6)$ polyunsaturated fatty acids in a mixed meal may decrease postprandial lipemia and markers of inflammation and endothelial activity in overweight men. J Nutr 2011, 141:816-821.

68. Chen W, Jump DB, Grant MB, Esselman WJ, Busik JV: Dyslipidemia, but not hyperglycemia, induces inflammatory adhesion molecules in human retinal vascular endothelial cells. Invest Ophthalmol Vis Sci 2003, 44:5016-5022

69. Seaton TB, Welle SL, Warenko MK, Campbell RG: Thermic effect of medium-chain and long-chain triglycerides in man. Am J Clin Nutr 1986, 44:630-634.

70. van Dijk SJ, Mensink M, Esser D, Feskens EJ, Muller M, Afman LA: Responses to high-fat challenges varying in fat type in subjects with different metabolic risk phenotypes: a randomized trial. PLoS One 2012, 7:e41388.

71. Peairs AD, Rankin JW, Lee YW: Effects of acute ingestion of different fats on oxidative stress and inflammation in overweight and obese adults. Nutr J 2011, 10:122.

72. Sacks FM, Campos H: Polyunsaturated fatty acids, inflammation, and cardiovascular disease: time to widen our view of the mechanisms. J Clin Endocrinol Metab 2006, 91:398-400.

73. Johnson $\mathrm{GH}$, Fritsche K: Effect of dietary linoleic acid on markers of inflammation in healthy persons: a systematic review of randomized controlled trials. J Acad Nutr Diet 2012, 112:1029-1041. 1041 e1021-1015. 
74. Kralova Lesna I, Suchanek P, Brabcova E, Kovar J, Malinska H, Poledne R: Effect of different types of dietary fatty acids on subclinical inflammation in humans. Physiol Res 2013, 62:145-152.

75. Bjermo H, Iggman D, Kullberg J, Dahlman I, Johansson L, Persson L, Berglund J, Pulkki K, Basu S, Uusitupa M, et al: Effects of n-6 PUFAs compared with SFAs on liver fat, lipoproteins, and inflammation in abdominal obesity: a randomized controlled trial. Am J Clin Nutr 2012, 95:1003-1012.

76. Blake GJ, Ridker PM: Are statins anti-inflammatory? Curr Control Trials Cardiovasc Med 2000, 1:161-165.

77. Rodriguez AL, Wojcik BM, Wrobleski SK, Myers DD Jr, Wakefield TW, Diaz JA: Statins, inflammation and deep vein thrombosis: a systematic review. J Thromb Thrombolysis 2012, 33:371-382.

78. Maki KC, Reeves MS, Farmer M, Griinari M, Berge K, Vik H, Hubacher R, Rains TM: Krill oil supplementation increases plasma concentrations of eicosapentaenoic and docosahexaenoic acids in overweight and obese men and women. Nutr Res 2009, 29:609-615.

79. Kiecolt-Glaser JK, Belury MA, Andridge R, Malarkey WB, Hwang BS, Glaser R: Omega-3 supplementation lowers inflammation in healthy middle-aged and older adults: a randomized controlled trial. Brain Behav Immun 2012, 26:988-995.

80. Lin PY, Huang SY, Su KP: A meta-analytic review of polyunsaturated fatty acid compositions in patients with depression. Biol Psychiatry 2010, 68:140-147.

81. Sijben JW, Calder PC: Differential immunomodulation with long-chain $n-3$ PUFA in health and chronic disease. Proc Nutr Soc 2007, 66:237-259.

82. Itariu BK, Zeyda M, Hochbrugger EE, Neuhofer A, Prager G, Schindler K, Bohdjalian A, Mascher D, Vangala S, Schranz M, et al: Long-chain n-3 PUFAs reduce adipose tissue and systemic inflammation in severely obese nondiabetic patients: a randomized controlled trial. Am J Clin Nutr 2012, 96:1137-1149.

83. Nelson TL, Stevens JR, Hickey MS: Inflammatory markers are not altered by an eight week dietary alpha-linolenic acid intervention in healthy abdominally obese adult males and females. Cytokine 2007, 38:101-106.

84. Sharman MJ, Volek JS: Weight loss leads to reductions in inflammatory biomarkers after a very-low-carbohydrate diet and a low-fat diet in overweight men. Clin Sci (Lond) 2004, 107:365-369.

85. Forsythe CE, Phinney SD, Fernandez ML, Quann EE, Wood RJ, Bibus DM, Kraemer WJ, Feinman RD, Volek JS: Comparison of low fat and low carbohydrate diets on circulating fatty acid composition and markers of inflammation. Lipids 2008, 43:65-77.

86. Munro IA, Garg ML: Dietary supplementation with long chain omega-3 polyunsaturated fatty acids and weight loss in obese adults. Obes Res Clin Pract 2013, 7:e173-e181.

87. Kratz M, Swarbrick MM, Callahan HS, Matthys CC, Havel PJ, Weigle DS: Effect of dietary n-3 polyunsaturated fatty acids on plasma total and high-molecular-weight adiponectin concentrations in overweight to moderately obese men and women. Am J Clin Nutr 2008, 87:347-353.

88. Berry SE, Miller GJ, Sanders TA: The solid fat content of stearic acid-rich fats determines their postprandial effects. Am J Clin Nutr 2007, $85: 1486-1494$

89. Dixon NC, Hurst TL, Talbot DC, Tyrrell RM, Thompson D: Active middle-aged men have lower fasting inflammatory markers but the postprandial inflammatory response is minimal and unaffected by physical activity status. J Appl Physiol (1985) 2009, 107:63-68.

90. Goris AH, Westerterp KR: Underreporting of habitual food intake is explained by undereating in highly motivated lean women. J Nutr 1999 129:878-882.

doi:10.1186/1475-2891-13-12

Cite this article as: Teng et al:: Modulation of obesity-induced inflammation by dietary fats: mechanisms and clinical evidence. Nutrition Journal 2014 13:12

\section{Submit your next manuscript to BioMed Central and take full advantage of:}

- Convenient online submission

- Thorough peer review

- No space constraints or color figure charges

- Immediate publication on acceptance

- Inclusion in PubMed, CAS, Scopus and Google Scholar

- Research which is freely available for redistribution

Submit your manuscript at www.biomedcentral.com/submit

C BioMed Central 